\title{
Assessment of annual effective dose due to radon concentrations in deep and shallow wells within Ekiti State, Nigeria
}

\author{
M.O. Isinkaye ${ }^{1, *}$ and Y. Ajiboye ${ }^{2}$ \\ ${ }^{1}$ Department of Physics, Ekiti State University, Ado-Ekiti, Nigeria. \\ 2 Department of Mathematical and Physical Sciences, Afe Babalola University, Ado-Ekiti (ABUAD), Nigeria.
}

Received 17 September 2016 / Accepted 29 March 2017

\begin{abstract}
Drinking water samples obtained from different groundwater sources in Ekiti State, Nigeria were assayed for radon concentration with the aid of a Durridge RAD7 electronic radon detector. In the three types of well considered, higher radon contents were found in hand-dug wells with manual pumps while hand-dug wells with removable covers presented the least radon content. The total annual effective dose incurred through the consumption of groundwater in the study area is found to be within the guideline value of $0.1 \mathrm{mSv}$ recommended by European Union and WHO.
\end{abstract}

Keywords: Ra-222 / radon detector / groundwater / dose assessment / natural radioactivity

\section{Introduction}

Radon is a gas, which belongs to the naturally occurring uranium and thorium radioactive decay series. It is generally produced through the radioactive decay of uranium- and thorium- bearing compounds in rocks and soil (Chen et al., 2011). Radon is one of the most widely dispersed naturally occurring radionuclides in the earth's environment. Out of the three isotopes of radon, only ${ }^{222} \mathrm{Rn}$ ( $3.8 \mathrm{~d}$ half-life), formed within the uranium series by the decay of ${ }^{226} \mathrm{Ra}$, is of interest as the other isotopes are very short-lived (Knuttson and Olofsson, 2002). Radon decays by $\alpha$-particle emission to generate radioactive decay products, which are also $\alpha$-emitters. Two of these decay products; ${ }^{214}$ Po and ${ }^{218}$ Po constitute about $90 \%$ of the total dose received by man and the environment due to radon exposure (Badhan et al., 2010). When radon decay products $\left({ }^{214} \mathrm{Po}\right.$ and $\left.{ }^{218} \mathrm{Po}\right)$ are inhaled, they deposit their energy into the sensitive tissues of the lungs causing damage to the DNA resulting in lung cancer. Radon gas is produced in rocks and moves through fractured and porous rocks by gaseous diffusion to dissolve in groundwater. The activity concentration of radon in groundwater is directly related to the concentration of uranium in the bedrocks through which the groundwater flows. The migration of radon in the ground includes emanation and diffusion from uranium-bearing mineral grains, diffusion through permeable rocks and soil, and transport by groundwater flow. Thus, groundwater in uranium-rich crystalline rocks environment often has elevated radon concentration compared to sedimentary rock environment, which are generally known to have low concentrations

\footnotetext{
* Corresponding author: matthewisinkaye@eksu.edu.ng
}

of these radionuclides. Radon is a major contributor to the radioactivity level of groundwater.

Humans are generally exposed to ionizing radiation through inhalation or ingestion of radon dissolved in utility water. Dissolved radon is ingested directly when water is consumed. Inhalation occurs when dissolved radon is released into the air upon water usage (Abdallah et al., 2007). The US Environmental Protection Agency (EPA) proposed a maximum contaminant level $(\mathrm{MCL})$ of $300 \mathrm{pCi} \mathrm{L}^{-1}\left(\approx 11.1 \mathrm{~Bq} \mathrm{~L}^{-1}\right)$ for radon concentration in public water supplies (USEPA, 1991; Krishan et al., 2014). Also, the European Commission (EC) recommended $100 \mathrm{~Bq} \mathrm{~L}^{-1}$ as the parametric value for radon concentration in utility water for the members of the public and this EC recommendation has been adopted by the World Health Organization (WHO). Several researchers around the globe have reported radon concentrations in drinking water much higher than these values (Horvath et al., 2000; Kozlowska et al., 2001; Badhan et al., 2010). The global average effective dose from the ingestion and inhalation of radon and its radioactive daughters in drinking water is estimated as $0.027 \mathrm{mSvy}^{-1}$ (UNSCEAR, 2008).

\section{Materials and methods}

Ekiti State is bounded on the east between coordinates $4^{\circ} 54^{\prime}$ and $5^{\circ} 47^{\prime}$, and on the north between coordinates $7^{\circ} 16^{\prime}$ and $8^{\circ} 04^{\prime}$ with an area of approximately $5300 \mathrm{~km}^{2}$ and elevation ranging between $1100 \mathrm{ft}$ and $1900 \mathrm{ft}$. Ekiti State is situated in the southwest geopolitical zone of Nigeria. The geographical map of Ekiti State showing the distribution of sampling points is presented in Figure 1. The extent of aeration is an important factor that determined the radon content of 


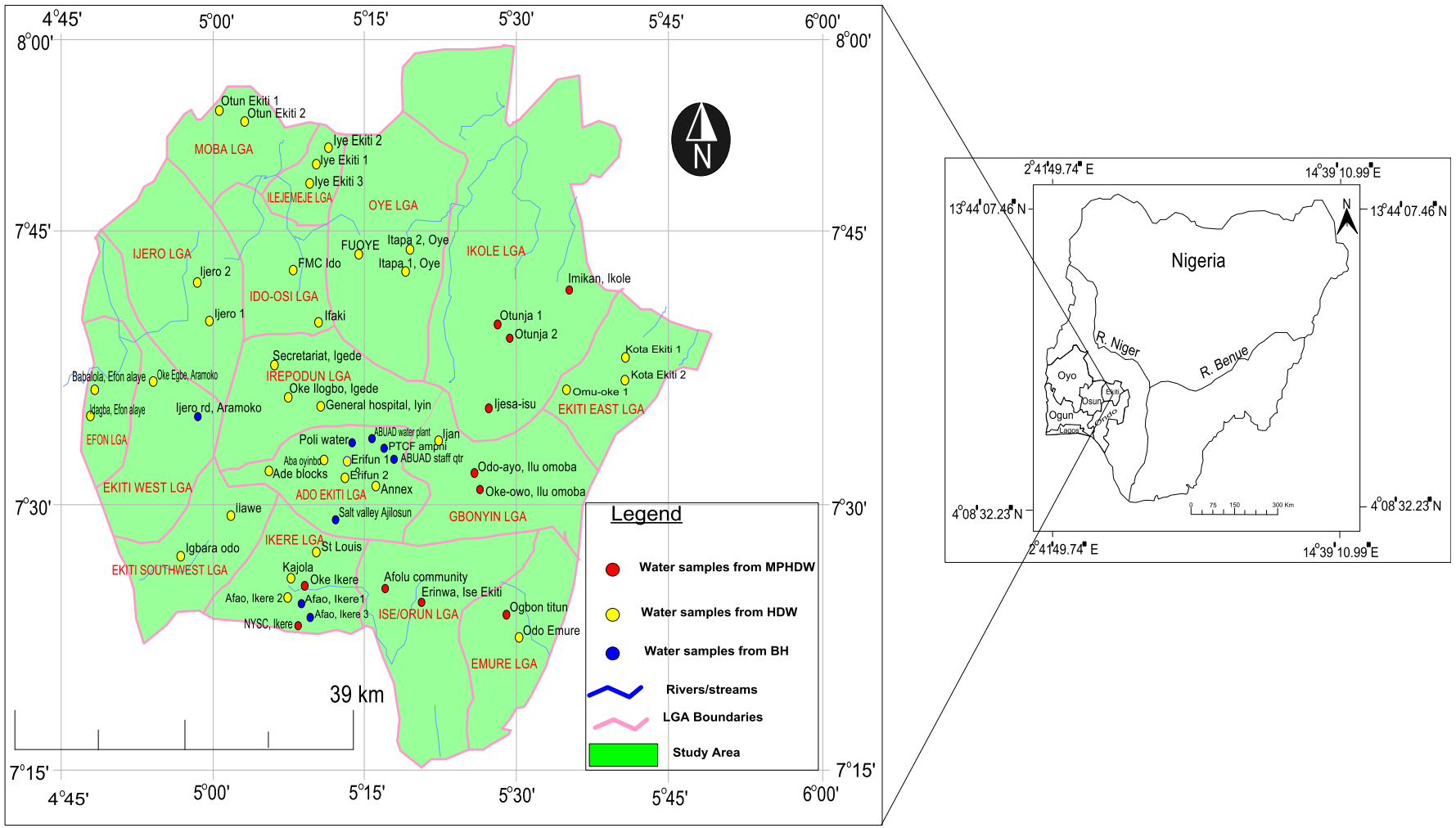

Fig. 1. Geographical map of Ekiti State showing the distribution of sampling points.

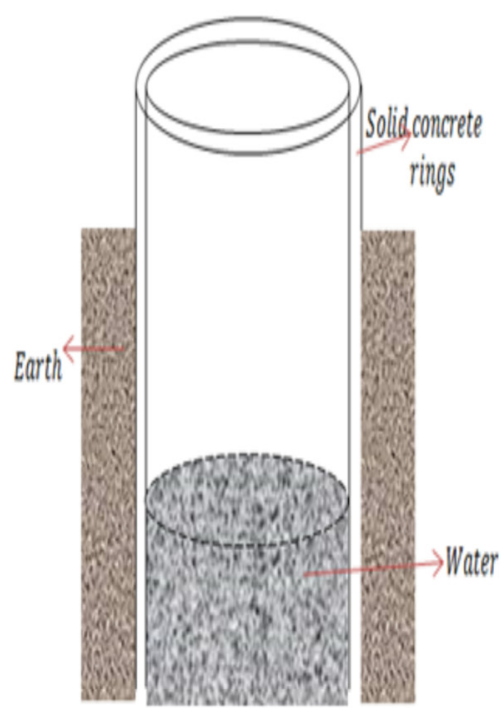

Hand-dug well

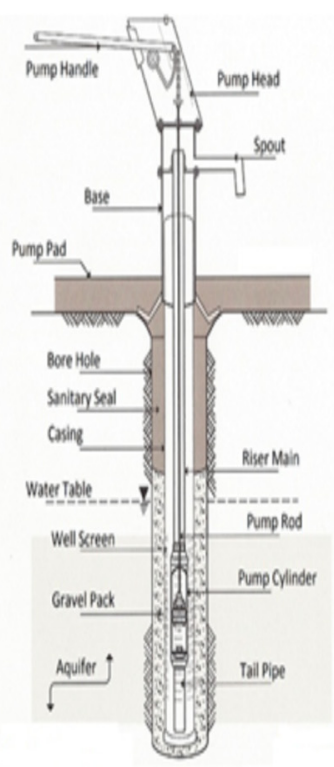

Source: www. clean-water-forlaymen.com water-well-diagram

Hand - dug well (Manual pump)

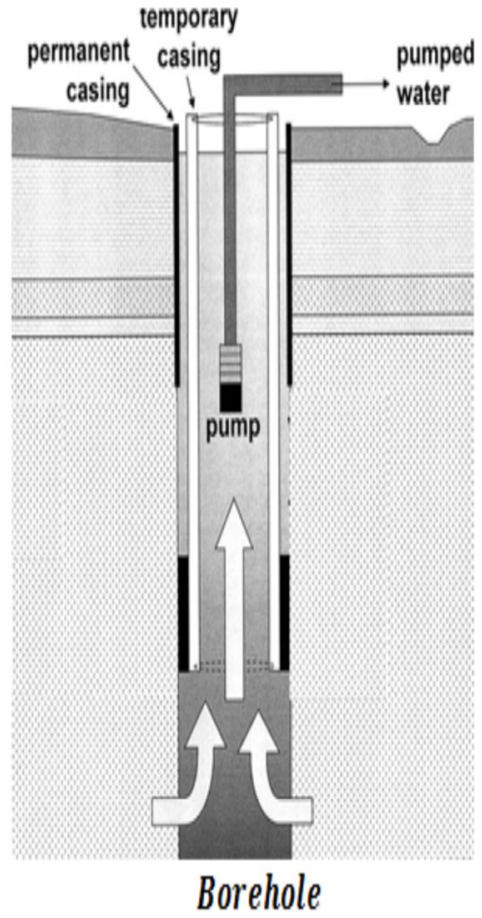

Fig. 2. Schematic diagram of the wells in the study location.

drinking water. Thus, water samples were collected at the fetching points and measured immediately in order to determine the actual public exposure levels. Three categories of wells were identified for the purpose of this study: deep wells (borehole), shallow wells (hand-dug with removable cover), and shallow wells (hand-dug with manual pump). The schematic diagram for the three well-types is shown in Figure 2. At the collection points, only one water sample was collected and measured in a four-cycle measurements and the average was reported in Table 1. 
Table 1. Statistics of radon concentration $\left(\mathrm{Bq} \mathrm{L}^{-1}\right)$, annual effective dose due to ingestion $\left(D_{\text {Wingestion }}\right)$ and inhalation $\left(D_{\text {Winhalation }}\right)$ of radon in groundwater.

\begin{tabular}{|c|c|c|c|c|c|c|c|}
\hline \multirow{2}{*}{$\frac{\text { Well type }}{\text { Statistics }}$} & \multirow[t]{2}{*}{ No of samples } & \multicolumn{2}{|c|}{ Concentration $\left(\mathrm{Bq} \mathrm{L}^{-1}\right)$} & \multicolumn{2}{|c|}{$D_{\text {Wingestion }}(\mathrm{mSv})$} & \multicolumn{2}{|c|}{$D_{\text {Winhalation }}(\mathrm{mSv})$} \\
\hline & & Range & Mean $\pm \sigma$ & Range & $\operatorname{Mean} \pm \sigma$ & Range & $\operatorname{Mean} \pm \sigma$ \\
\hline $\mathrm{BH}$ & 8 & $13.4-105.8$ & $30.9 \pm 28.7$ & $0.034-0.270$ & $0.079 \pm 0.073$ & $0.034-0.267$ & $0.078 \pm 0.072$ \\
\hline MPHDW & 11 & $2.5-206.1$ & $81.2 \pm 68.1$ & $0.006-0.527$ & $0.208 \pm 0.173$ & $0.006-0.519$ & $0.205 \pm 0.172$ \\
\hline Overall & 52 & $2.1-206.1$ & $34.3 \pm 42.6$ & $0.005-0.527$ & $0.088 \pm 0.109$ & $0.005-0.519$ & $0.087 \pm 0.107$ \\
\hline
\end{tabular}

BH: borehole; HDW: hand-dug well; MPHDW: manual pump hand-dug well.

Water samples from hand-dug wells with removable cover were collected with the aid of bailer (bucket attached to a long rope). The collection bottle is then submerged into the bucket and capped underwater (Kotrappa et al., 1990). Samples from hand-dug wells with manual pumps were obtained by pumping the water out with their locally fabricated pumps, while samples from boreholes were collected directly from the tap. In order to obtain a representative sample, the water from the tap was allowed to run for several minutes before collection. Each sample was fed into a $250 \mathrm{~mL}$ Rad- $\mathrm{H}_{2} \mathrm{O}$ vial while ensuring that no bubbling takes place in the process. Radon concentration measurements were carried out at the various sampling sites to avoid fluctuation in radon level due to aeration and bubbling. Radon concentrations in analyzed groundwater samples were carried out with the aid of a Durridge Co. Ltd, USA manufactured RAD7 electronic radon detector coupled to $\mathrm{RAD}-\mathrm{H}_{2} \mathrm{O}$ accessories utilizing a closed loop aeration concept consisting of three components:

- the RAD7 or radon monitor;

- the water vial with aerator;

- the tube of desiccant, supported by retort stand.

In the present work, measurements were done on-site, therefore no decay-correction was carried out. The radon level is calculated automatically by RAD7 and reported in $\mathrm{pCi} \mathrm{L}^{-1}$. The resulting ${ }^{222} \mathrm{Rn}$ activity concentrations are then expressed in $\mathrm{Bq} \mathrm{L}^{-1}$ (disintegration per second per litre) with $2 \sigma$ uncertainties. All measurements were carried out following the ISO 13164 standards of test method using two-phase liquid scintillation counting for ${ }^{222} \mathrm{Ra}$ in water. The detection limit of the RAd7 detector is $0.004 \mathrm{~Bq} \mathrm{~L}^{-1}$.

\subsection{Estimation of annual effective dose}

Dissolved radon in groundwater may lead to radiation exposure from the ingestion of drinking water and from the inhalation of radon released in air when water is used (UNSCEAR, 2000). The radiological hazards incurred by humans through the ingestion and inhalation of dissolved radon in utility water were estimated in terms of the effective radiation dose received by the general public as a result of regular usage of groundwater. The annual effective dose due to ingestion of radon in water was estimated using the formula presented by UNSCEAR (2000) as:

$$
D_{W}(\text { ingestion })=C_{R n W} \times C_{R W} \times D C F,
$$

where $D_{W \text { (ingestion) }}$ is the annual effective dose given $\left(\mathrm{mSvy}^{-1}\right), C_{R n W}$ is the experimentally determined radon-222 concentration in water $\left(\mathrm{BqL}^{-1}\right), C R_{W}$ is the annual water consumption rate $\left(\mathrm{Ly}^{-1}\right)$ and $D C F$ is the ingested dose conversion factor for ${ }^{222} \mathrm{Rn}\left(\mathrm{SvBq}^{-1}\right)$. For the purpose of effective ingestion dose calculation, a dose conversion factor of $3.5 \times 10^{-9} \mathrm{~Sv} \mathrm{~Bq}^{-1}$ as suggested by UNSCEAR was used. Assuming that an adult (age $\geq 18$ ) consumes an average of $2 \mathrm{~L}$ of water per day (Somashekar and Ravikumar, 2010), the annual water consumption rate equal to $730 \mathrm{~L} \mathrm{y}^{-1}$ was employed in this study.

Also, the annual effective dose due to inhalation of dissolved radon in water is estimated using the formula suggested in UNSCEAR (2000). Mathematically, the formula is given as:

$$
D_{W}(\text { inhalation })=C_{R n W} \times A W R \times O C F \times E F \times D C F,
$$

where, $D_{W \text { (inhalation) }}$ is the annual effective dose due to inhalation of radon release to air from water $\left(\mathrm{mSv} \mathrm{y}^{-1}\right), C_{R n W}$ is the experimentally determined radon concentration in water $\left(\mathrm{Bq} \mathrm{L}^{-1}\right), A W R$ is the air-water concentration ratio given as $10^{-4}, O C F$ is the indoor occupancy factor $\left(7000 \mathrm{~h} \mathrm{y}^{-1}\right), E F$ is the indoor radon-progeny equilibrium factor $(E F=0.4)$ and $D C F$ is the inhalation dose conversion factor for ${ }^{222} \mathrm{Rn}$ $\left(D C F=9.0 \times 10^{-9} \mathrm{~Sv} \mathrm{~Bq}^{-1} \mathrm{~h}^{-1} \mathrm{~m}^{3}\right)$.

\section{Results and discussion}

The measured radon concentration in drinking water samples collected from three different well types in Ekiti State, Nigeria are presented in Table 1. For deep well (borehole), the radon concentration range from 13.4 to $105.8 \mathrm{BqL}^{-1}$ with a mean value of $30.9 \mathrm{~Bq} \mathrm{~L}^{-1}$, hand-dug well with removable cover has radon concentration ranging from 2.1 to $43.7 \mathrm{~Bq} \mathrm{~L}^{-1}$ with a mean value of $19.5 \mathrm{~Bq} \mathrm{~L}^{-1}$ while hand-dug well with manual pump has radon concentration ranging from 2.5 to $206.1 \mathrm{~Bq} \mathrm{~L}^{-1}$ with a mean of $81.2 \mathrm{~Bq} \mathrm{~L}^{-1}$. From the results, it is clearly seen that hand-dug wells with manual pumps have the highest mean radon concentration. This is attributable to the accumulation and long residence time of the water samples within the well. Also, this type of well has little or no aeration mechanism, therefore, the dissolved radon is higher than other well types. Due to the high radon content of drinking water from this type of well, it is advisable to allow the water to 
aerate before consumption, so as to give time for water to degas its radon content. The overall radon concentration in all the drinking water samples ranged from 2.1 to $206.1 \mathrm{~Bq} \mathrm{~L}^{-1}$ with an overall mean value of $34.3 \pm 43.0 \mathrm{~Bq} \mathrm{~L}^{-1}$. Several health and environmental protection agencies have recommended different safe criteria for radon concentration in drinking water for members of the public (Mittal et al., 2016). The results of this work were assessed with those criteria. The mean radon concentrations obtained for the three well types fall within the criteria level suggested by USEPA (1991), EC (2001) and UNSCEAR (2008).

The annual mean effective dose due to ingestion of radon in the analyzed water samples is presented in Table 1. As shown in the Table, the mean annual effective dose due to ingestion varied from $0.050 \pm 0.032 \mathrm{mSv}$ in hand-dug wells to $0.208 \pm 0.173 \mathrm{mSv}$ with an overall mean value of $0.088 \mathrm{mSv}$. The mean value obtained in this study is higher than the mean value of $0.002 \mathrm{mSv}$ estimated as the world average annual effective dose due to ingestion of radon in drinking water by UNSCEAR (2000). The annual mean effective dose due to inhalation is also presented in Table 1 and as seen from the Table, the mean annual effective dose due to inhalation range from $0.005 \mathrm{mSv}$ in hand-dug wells to $0.519 \mathrm{mSv}$ in hand-dug wells with manual pumps with an overall average value of $0.087 \mathrm{mSv}$. The total annual effective dose due to ingestion and inhalation of radon and its progenies in the investigated water samples in the study area varies from $0.099 \mathrm{mSv}$ to $0.412 \mathrm{mSv}$ with an average value of $0.174 \pm 0.216 \mathrm{mSv}$. The average total annual effective dose of all the studied water samples is found to be within the guideline level of $0.1 \mathrm{mSv}$ set by European Union (EC, 1998) and WHO (2004). The high value of the standard deviation is a reflection of the variability of radon concentrations in underground water in the study area. Variability in radon concentration may be linked to uranium/radium content in the bedrock. A compressive effort to characterize the natural radionuclides in the studied area is in progress.

\section{Conclusion}

Radon concentration in groundwater samples collected from deep and shallow wells used as sources of utility water in Ekiti State, Nigeria have been measured in this study. The results show that hand-dug well with manual pumping device presents the highest mean concentration of ${ }^{222} \mathrm{Rn}$ compared with borehole and hand-dug well with removable cover. The total effective dose per annum due to ingestion and inhalation of radon in the analyzed water samples varies from $0.099 \mathrm{mSv}$ to $0.412 \mathrm{mSv}$ with a mean value of $0.174 \pm 0.216 \mathrm{mSv}$. The total effective dose incur through the utilization of groundwater in the area is found to be within the limit of $0.1 \mathrm{mSv} \mathrm{y}^{-1}$ as recommended by European Union and WHO.

\section{References}

Abdallah SM, Habib RR, Nuwayhid RY, Chatila M, Katul G. 2007. Radon measurements in well and spring water in Lebanon. Radiat. Meas. 42(2): 298-303.

Badhan K, Mehra R, Sonkawade RG. 2010. Measurement of radon concentration in ground water using RAD7 and assessment of average annual dose in the environs of NITJ, Punjab, India. Indian J. Pure Appl. Phys. 48: 508-511.

Chen J, Moir D, Sorimachi A, Tokonami S. 2011. Characteristics of thoron and thoron progeny in Canadian homes. Radiat. Environ. Biophys. 50: 85-89.

EC. 1998. Council Directive 98/83/EC of 3 November 1998 on the quality of water intended for human consumption. Official Journal of the European Communities, L330: 32-54.

EC. 2001. Commission recommendation of 20 December 2001 on the protection of the public against exposure to radon in drinking water supplies. Official Journal of the European Communities, L344: 85-88.

Horvath A, Bohus LO, Urbani F, Marx G, Piroth A, Greaves ED. 2000. Radon concentration in hot springs waters in northern Venezuela. J. Environ. Radioact. 47: 127-133.

Knuttson G, Olofsson B. 2002. Radon content in groundwater from drilled wells in Stockholm region of Sweden. NGU-Bull. 439: 79-85.

Kotrappa P, Dempsey JC, Ramsey RW, Stieff LR. 1990. A practical EPerm system for indoor ${ }^{222} \mathrm{Rn}$ measurement. Health Phys. 58: 461-466.

Kozlowska B, Hetman A, Dorda J, Zipper W. 2001. Radon-enriched spring waters in the south of Poland. Radiat. Phys. Chem. 61: 677678.

Krishan G, Rao MS Kumar CP. 2014. Radon concentration in ground water of east coast of west Bengal, India. J. Radioanal. Nucl. Chem. 303: 2221-2225.

Mittal S, Rani A, Mehra R. 2016. Estimation of radon concentration in soil and groundwater samples of Northern Rajasthan, India. J. Radiat. Res. Appl. Sci. 9: 125-130.

Somashekar RK, Ravikumar P. 2010. Radon concentration in groundwater of Varahi and Markandeya river basins, Karnataka State, India. J. Radioanal. Nucl. Chem. 285: 343-351.

UNSCEAR. 2000. United Nations Scientific Committee on the Effect of Atomic Radiation, Sources and effects of ionizing radiation. Report to General Assembly with Scientific Annexes. United Nations, New York: UNSCEAR.

UNSCEAR. 2008. United Nations Scientific Committee on the Effect of Atomic Radiation. Sources and effects of ionizing radiation. Report to General Assembly with Scientific Annexes. United Nations, New York: UNSCEAR.

USEPA. 1991. United States Environmental Protection Agency, Federal Register 40 parts 141 and 142: National primary drinking water regulations. Radionuclides: proposed rule. U.S.: U.S. Government Printing Office.

WHO. 2004. World Health Organization guidelines for drinking water quality, 3rd ed., Vol. 1. Geneva, Switzerland: World Health Organization.

Cite this article as: Isinkaye MO, Ajiboye Y. 2017. Assessment of annual effective dose due to radon concentrations in deep and shallow wells within Ekiti State, Nigeria. Radioprotection 52(3): 167-170 